Page 1 of 2

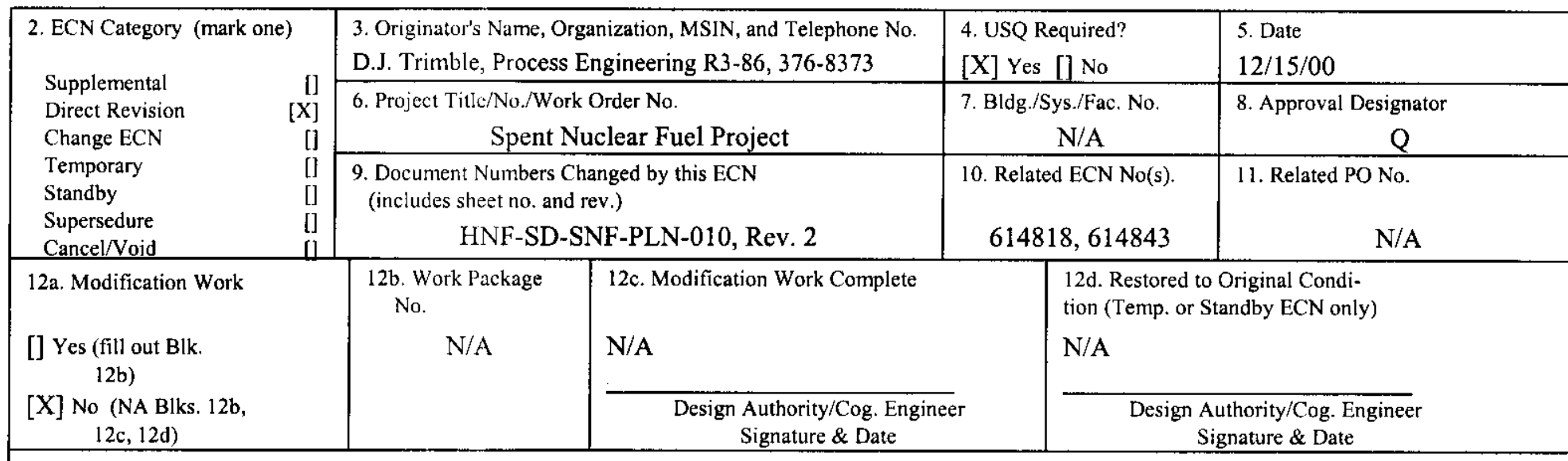

13a. Description of Change

13b. Design Baseline Document? [] Yes [X] No

Updates the Characterization Management Plan for Hanford K Basin SNF Project to reflect corrective actions to SNF Project Worker Assessment SNF-KP-WA-WM-20001756. Organizational responsibilities interfaces and functional responsibilities were updated to current status. Specific needs of SNF Project Sludge Handling Project are more clearly defined and separated from those requirements for fuel (i.e., "SNF") characterization. Referenced procedures were updated to those in current use.

USQ Screening Number: $k-00-15 / 8$

\section{4a. Justification (mark one) \\ Criteria Change [] \\ Design Improvement $\quad[\mathrm{X}]$ \\ Environmental [] \\ Facility Deactivation [] \\ As-Found \\ Facilitate Const [] \\ Const. Error/Omission [] \\ Design Error/Omission[]}

15. Distribution (include name, MSIN, and no. of copies)

See distribution 14b. Justification Details

Provides corrective actions in response to SNF Project Worker Assessment SNF-KP-WA-WM-20001756. 


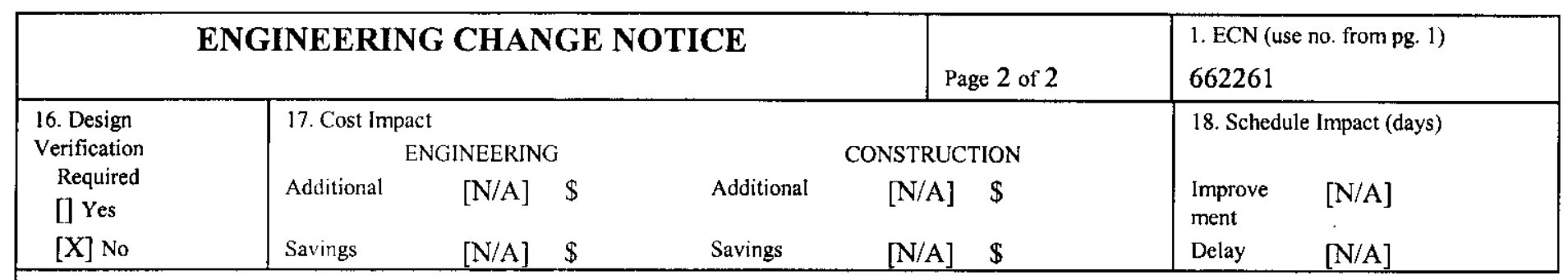

19. Change Impact Review: Indicate the related documents (other than the engineering documents identified on Side 1)

that will be affected by the change described in Block 13. Enter the affected document number in Block 20.

$$
\text { SDD/DD }
$$

Functional Design Criteria

Operating Specification

Criticality Specification

Conceptual Design Report

Equipment Spec.

Const. Spec.

Procurement Spec.

Vendor Information

OM Manual

FSARSAR

Safety Equipment List

Radiation Work Pernit

Environmental Impact Statement

Environmental Repon

Environmental Permit
[]

[]

[]

[]

[]

[]

[]

[]

[]

[]

[]

[]

[]

[1]

[]
Seismic/Stress Analysis

Stress/Design Report

Interface Control Drawing

Calibration Procedure

Installation Procedure

Maintenance Procedure

Engineering Procečure

Operating Instruction

Operating Procedure

Operational Safety Requirement

IEFD Drawing

Cell Anangement Drawing

Essential Material Specification

Fac. Proc. Samp. Schedule

Inspection Plan

lnventory Adjustment Request

]

[]

[]

[]

[]

[]

[]

[]

[]

[]

[]

[1] Process Control Manual/Plan

[1] Process Flow Chart

[] Purchase Requisition

[1] Tickler File

[] N/A

Tank Calibration Manual
Health Physics Procedure
Spares Multiple Unit Listing
Test Procedures/Specification
Component Index
ASME Coded ltern
Hurnan Factor Consideration
Computer Software
Electric Circuit Schedule
ICRS Procedure
Process Control Manual/Plan
Process Flow Chart
Purchase Requisition
Tickler File
N/A

20. Other Affected Documents: (NOTE: Documents listed below will not be revised by this ECN.) Signatures below indicate that the signing organization has been notified of other affected documents listed below.

HNF-SD-SNF-RPT-007, Rev. 3
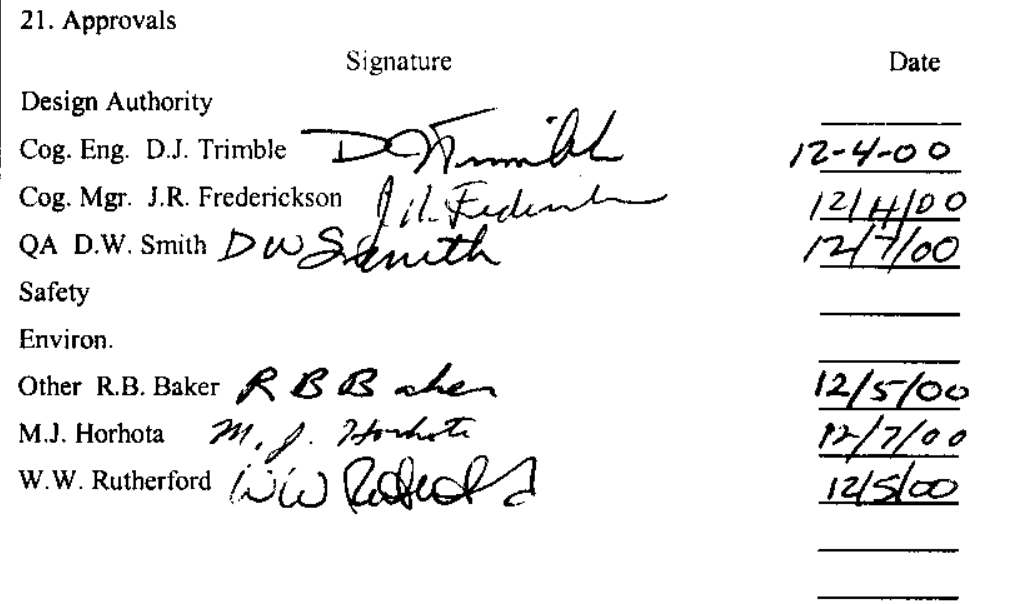

Design Agent

Signature

Date

PE

QA

Safety

Design

Environ.

Other

DEPARTMENT OF ENERGY

Signature or a Control Number that tracks the Approval Signature

ADDITIONAL 


\section{DISTRIBUTION SHEET}

\begin{tabular}{|c|c|c|c|c|c|}
\hline \multirow{2}{*}{$\begin{array}{l}\text { To } \\
\text { Distribution }\end{array}$} & \multirow{2}{*}{\multicolumn{3}{|c|}{$\begin{array}{l}\text { From } \\
\text { Process Engineering }\end{array}$}} & \multicolumn{2}{|l|}{ Page 1 of 1} \\
\hline & & & & \multicolumn{2}{|l|}{ Date $12 / 15 / 00$} \\
\hline \multirow{2}{*}{\multicolumn{4}{|c|}{$\begin{array}{l}\text { Project Title/Work Order } \\
\text { Characterization Program Management Plan for Hanford K Basin Spent Nuclear Fuel Project } \\
\text { (OCRWM) }\end{array}$}} & \multicolumn{2}{|l|}{ EDT No. N/A } \\
\hline & & & & \multicolumn{2}{|c|}{ ECN No. 662261} \\
\hline Name & MSIN & $\begin{array}{l}\text { Text } \\
\text { With All } \\
\text { Attach. }\end{array}$ & Text Only & $\begin{array}{l}\text { Attach./ } \\
\text { Appendix } \\
\text { Only }\end{array}$ & $\begin{array}{c}\text { EDT/ECN } \\
\text { Only }\end{array}$ \\
\hline
\end{tabular}

Spent Nuclear Fuel Project

$\begin{array}{lll}\text { J. Aberfah } & \mathrm{P} 7-27 & \mathrm{X} \\ \text { R.B. Baker } & \mathrm{H} 0-40 & \mathrm{X} \\ \text { S.A. Chastain } & \mathrm{H} 0-40 & \mathrm{X} \\ \text { D.A. Dodd } & \mathrm{T} 6-50 & \mathrm{X} \\ \text { J.R. Frederickson } & \mathrm{R} 3-86 & \mathrm{X} \\ \text { O.M. Holgado } & \mathrm{R} 3-81 & \mathrm{X} \\ \text { M.J. Horhota } & \mathrm{T} 3-02 & \mathrm{X} \\ \text { B.J. Makenas } & \mathrm{H} 0-40 & \mathrm{X} \\ \text { R.L. McCormack } & \mathrm{R} 3-13 & \mathrm{X} \\ \text { K.L. Pearce } & \mathrm{G} 1-23 & \mathrm{X} \\ \text { C.A. Peterson } & \mathrm{K} 9-21 & \mathrm{X} \\ \text { S.H. Peck } & \mathrm{R} 3-86 & \mathrm{X} \\ \text { W.W. Rutherford } & \mathrm{G} 1-23 & \mathrm{X} \\ \text { D.W. Smith } & \mathrm{S} 2-48 & \mathrm{X} \\ \text { J.A. Swenson } & \mathrm{X} 3-78 & \mathrm{X} \\ \text { R.M. Suyama } & \mathrm{R} 3-13 & \mathrm{X} \\ \text { D.J. Trimble } & \mathrm{R} 3-86 & \mathrm{X} \\ \text { L.B. McDaniel } & \mathrm{R} 3-13 & \mathrm{X} \\ \text { K.L. Silvers } & \mathrm{K} 9-08 & \mathrm{X} \\ \text { DOE Reading Room } & \mathrm{H} 2-53 & \mathrm{X} \\ \text { Sludge Handling Project File A-13b } & \mathrm{G} 1-23 & \mathrm{X} \\ \text { Central Files } & \mathrm{B} 1-07 & \mathrm{X} \\ \text { SNF Project Files } & \mathrm{R} 3-11 & \mathrm{X}\end{array}$




\section{Characterization Program Management Plan for Hanford K Basin Spent Nuclear Fuel Project (OCRWM)}

Prepared for the U.S. Department of Energy Assistant Secretary for Environmental Management

Project Hanford Management Contractor for the

U.S. Department of Energy under Contract DE-AC06-96RL13200

Fluor Hanford

P.O. Box 1000

Richland, Washington 
HNF-SD-SNF-PLN-010

Revision 3

ECN 662261

\title{
Characterization Program Management Plan for Hanford K Basin Spent Nuclear Fuel Project (OCRWM)
}

\author{
Division: SNF \\ R.B. Baker \\ D. J. Trimble \\ Fluor Hanford
}

Date Published

December 2000

Prepared for the U.S. Department of Energy

Assistant Secretary for Environmental Management

Project Hanford Management Contractor for the

U.S. Department of Energy under Contract DE-AC06-96RL13200

\section{Fluor Hanford}

P.O. Box 1000

Richland, Washington
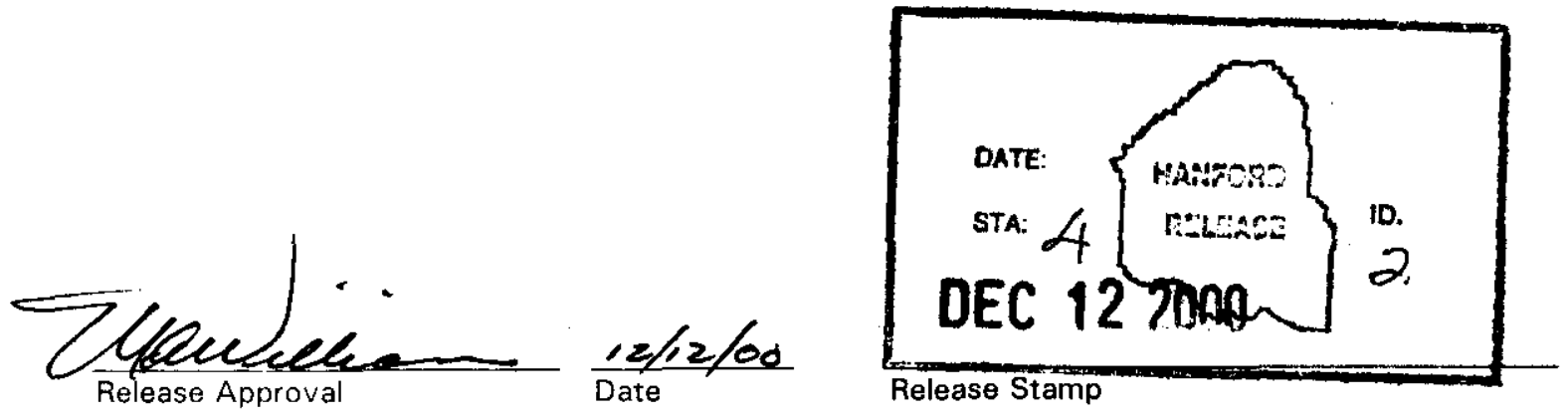
TRADEMARK DISCLAIMER

Reference herein to any specific commercial product, process, or service by trade name, trademark, manufacturer, or otherwise, does not necessarily constitute or imply its endorsement, recommendation, or favoring by the United States Government or any agency thereof or its contractors or subcontractors.

This report has been reproduced from the best available copy. Available in paper copy and microfiche.

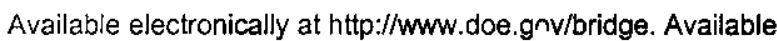
for a processing fee to the U.S. Department of Energy and its contractors, in paper, from:

U.S. Department of Energy

Office of Scientific and Technical Information

P.O. Box 62

Oak Ridge, TN 37831-0062

phone: $865-576-8401$

fax: 865-576-5728

email: reports@adonis.osti.gov(423) 576-8401

Available for sale to the public, in paper, from:

U.S. Department of Commerce

National Technical Information Service

5285 Port Royal Road

Springfield, VA 22161

phone: 800-553-6847

fax: 703-605-6900

email: orders@ ntis.fedworld.gov

online ordering: http://www.ntis.gov/ordering.htm

Printed in the United States of America

Total Pages: 28

HNF-SD-SNF- PLN-010, N 3 


\section{RECORD OF REVISION}

(2) Title

Characterization Program Management Plan for Hanford K Basin Spent Nuclear Fuel Project (OCRWM) CHANGE CONTROL RECORD

\begin{tabular}{|c|c|c|c|}
\hline \multirow[t]{2}{*}{ (3) Revision } & \multirow[t]{2}{*}{ (4) Description of Change - Replace, Add, and Delete Pages } & \multicolumn{2}{|c|}{ Authorized for Release } \\
\hline & & (5) Cog. Engr. & (6) Cog. Mgr. \\
\hline 0 & Initial release EDT $610184,10 / 18 / 95$ & L.A. Lawrence & R.P. Omberg \\
\hline 1 & ECN $164818,5 / 14 / 98$ & L.A. Lawrence & R.P. Omberg \\
\hline 2 & ECN $614843,7 / 19 / 99$ & D.J. Trimble & D.J. Trimble \\
\hline${ }^{3}$ RS & $\begin{array}{l}\text { ECN } 662261 \text { - A general revision incorporating corrective } \\
\text { actions to SNF Project Worker Assessment } \\
\text { SNF-KP-WA-WM-20001756. Organizational charts and } \\
\text { interfaces were updated. }\end{array}$ & Dof. Trimble & $\begin{array}{l}\text { J.R. Frederickson } \\
\text { /1Fuduni }\end{array}$ \\
\hline & & & \\
\hline & & & \\
\hline & & & \\
\hline & & & \\
\hline & & & \\
\hline & & & \\
\hline & & & \\
\hline & & & \\
\hline & & & \\
\hline & & & \\
\hline & & & \\
\hline & & & \\
\hline & & . & \\
\hline & & & \\
\hline & & & \\
\hline & & & \\
\hline & & & \\
\hline & & & \\
\hline & & & \\
\hline & & & \\
\hline & & & \\
\hline & & & \\
\hline & & & \\
\hline & & & \\
\hline & & & \\
\hline 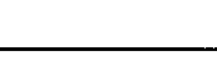 & 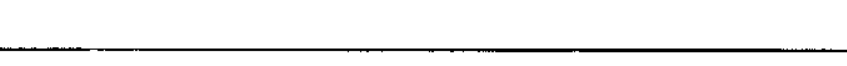 & & \\
\hline
\end{tabular}




\section{Executive Summary}

The management plan developed to characterize the K Basin spent nuclear fuel (SNF) and sludge was originally developed for Westinghouse Hanford Company and Pacific Northwest National Laboratory to work together on a program to provide characterization data to support removal, conditioning, and subsequent dry storage of the SNF stored at the Hanford K Basins. The plan also addressed necessary characterization for the removal, transport, and storage of the sludge from the Hanford K Basins. This plan was revised in 1999 (i.e., Revision 2) to incorporate actions necessary to respond to the deficiencies revealed as the result of Quality Assurance surveillances and audits in 1999 with respect to the fuel characterization activities.

Revision 3 to this Program Management Plan responds to a Worker Assessment resolution determined in Fical Year 2000. This revision includes an update to current organizational structures and other revisions needed to keep this management plan consistent with the current project scope. The plan continues to address both the SNF and the sludge accumulated at K Basins. Most activities for the characterization of the SNF have been completed. Data validation, Office of Civilian Radioactive Waste Management (OCRWM) document reviews, and OCRWM data qualification are the remaining SNF characterization activities. The transport and storage of $\mathrm{K}$ Basin sludge are affected by recent path forward revisions. These revisions require additional laboratory analyses of the sludge to complete the acquisition of required supporting engineering data. Hence, this revision of the management plan provides the overall work control for these remaining SNF and sludge characterization activities given the current organizational structure of the SNF Project. 
HNF-SD-SNF-PLN-010, Rev. 3

This page intentionally left blank. 


\section{TABLE OF CONTENTS}

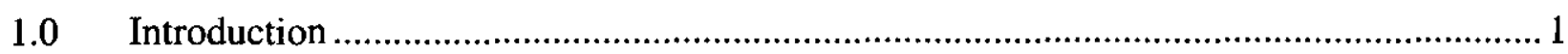

2.0 Scope, Objectives, and Program Responsibilities ...........................................................

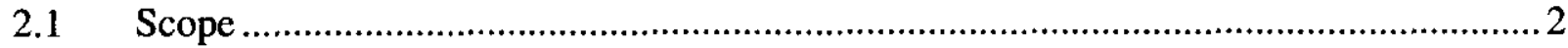

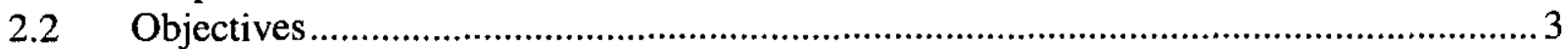

2.3 Program Responsibilities.......................................................................................

3.0 Program Management and Organization.....................................................................

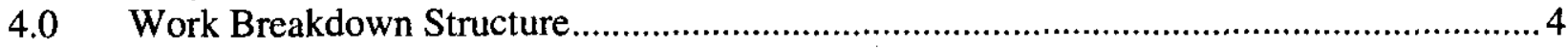

5.0 Program Element Areas of Responsibility .................................................................... 4

5.1 Plan for Characterization of K Basin SNF and Sludge ..............................................4

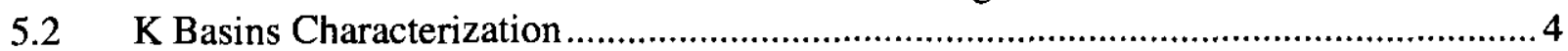

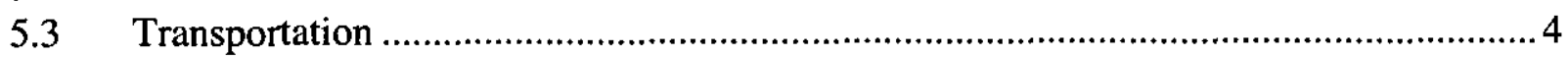

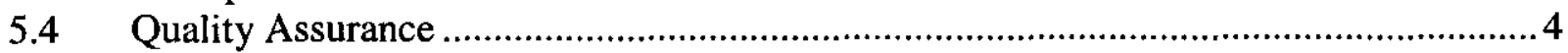

5.4.1 QA Organization Support for the SNF Project Characterization Activities ...........5

5.4.2 OCRWM QA Program......................................................................................

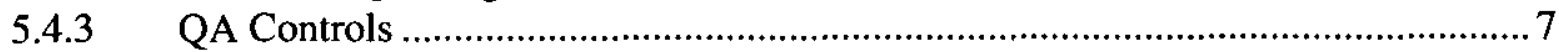

5.4.4 Scientific Investigations .................................................................................. 10

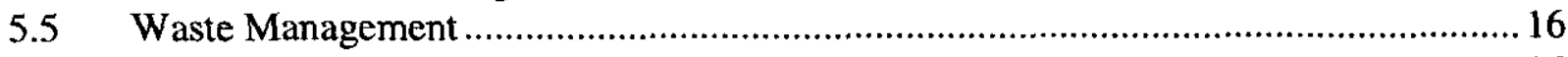

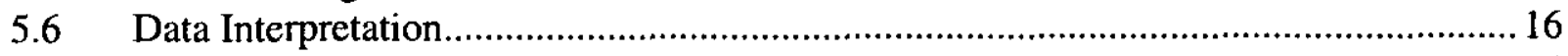

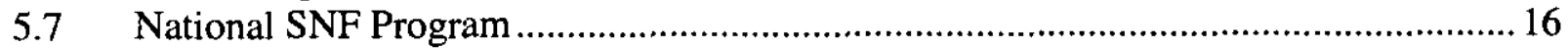

6.0 Program Interfaces and Communications .................................................................... 16

6.1 Management Points of Contact ............................................................................... 16

6.2 Lead Engineers, Principal Investigators, and Task Team Leaders ................................17

6.3 Interface with SNF Projects .................................................................................. 17

6.4 Interfaces with Other Hanford Projects....................................................................... 17

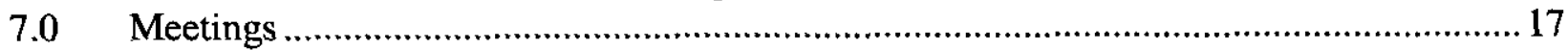

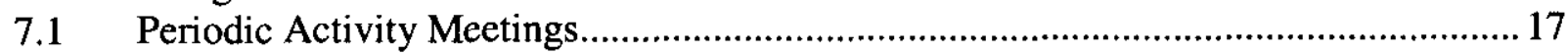

8.0 Reports and Documentation ..........................................................................................

8.1 Topical Reports and Open Literature Publications ....................................................... 17

8.2 Plans, Requirements, and Routine Correspondence.................................................... 18

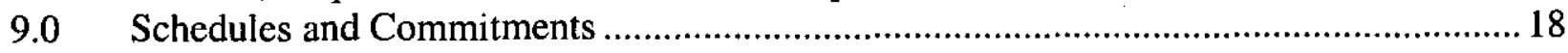

$9.1 \quad$ Overall Project Schedules ................................................................................... 18

9.2 Characterization Activities Schedule and Milestones ……………............................... 18

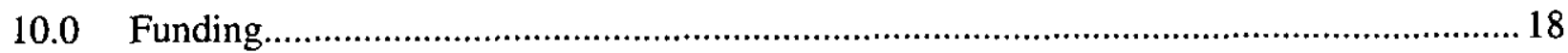

11.0 Program Management Plan Revisions ....................................................................... 19

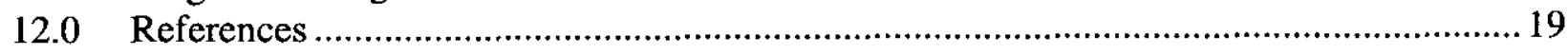

\section{LIST OF TABLES}

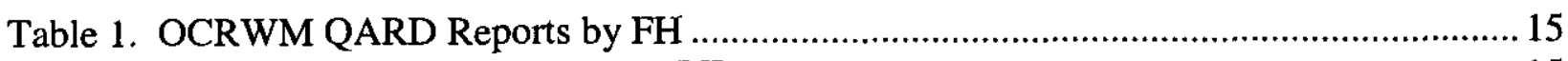

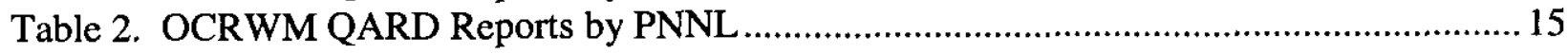


HNF-SD-SNF-PLN-010, Rev. 3

\section{LIST OF FIGURES}

Figure 1. SNF Project Organization Structure for Achieving Quality in Characterization

Activities.

\section{List of Acronyms}

$\begin{array}{ll}\text { AP } & \text { Administrative Procedure } \\ \text { DQO } & \text { Data Quality Objective } \\ \text { EIS } & \text { Environmental Impact Statement } \\ \text { EPA } & \text { United States Environmental Protection Agency } \\ \text { FH } & \text { Fluor Hanford, Inc. } \\ \text { FY } & \text { Fiscal Year } \\ \text { MCO } & \text { Multi-Canister Overpack } \\ \text { MYPP } & \text { Mulit-Year Program Plan } \\ \text { OCRWM } & \text { Office of Civilian Radioactive Waste Management } \\ \text { PMP } & \text { Program Management Plan } \\ \text { PNNL } & \text { Pacific Northwest National Laboratory } \\ \text { QA } & \text { Quality Assurance } \\ \text { QAPD } & \text { Quality Assurance Program Desciption } \\ \text { QAPP } & \text { Quality Assurance Program Plan } \\ \text { QARD } & \text { Quality Assurance Requirements and Description } \\ \text { QC } & \text { Quality Control } \\ \text { RL } & \text { United States Department of Energy, Richland Operations Office } \\ \text { ROD } & \text { Record of Decision } \\ \text { SAP } & \text { Sampling and Analysis Plan } \\ \text { SNF } & \text { Spent Nuclear Fuel } \\ \text { TGA } & \text { Thermo-Gravimetric Analysis } \\ \text { WBS } & \text { Work Breakdown Structure } \\ \text { WIPP } & \text { Waste Isolation Pilot Plant }\end{array}$


HNF-SD-SNF-PLN-010, Rev. 3

\section{$1.0 \quad$ INTRODUCTION}

Fluor Hanford, Inc. $(\mathrm{FH})$ has responsibility for management of the characterization activities, including cost and schedule, and disposition of technical information to the Spent Nuclear Fuel (SNF) Project. This responsibility was previously held by Westinghouse Hanford Company, then by Duke Engineering \& Services Hanford, Inc. This Program Management Plan (PMP) addresses both the SNF and the bulk sludge at the Hanford K Basins. For the SNF, the Pacific Northwest National Laboratory (PNNL) has had responsibility for managing the technical work at the laboratories needed to support the objectives identified by $\mathrm{FH}$, and responsibility to serve as a technical advisor to FH. For the sludge, the Hanford 222-S Laboratory and PNNL 325 Laboratory have responsibility for performing required analyses, and both provide technical advice to FH depending on needs. Overall, the characterization activities support resolution of the Hanford SNF Project Path Forward storage issues.

As a matter of definition within the current PMP when the term "SNF" is used by itself, it refers specifically to "spent nuclear fuel" elements and/or pieces of spent nuclear fuel greater than 0.25 inches. The term "sludge" refers to any particulate material equal to or less than 0.25 inches that has accumulated in the basins, storage canisters, or remote pits at the $\mathrm{K}$ Basins (this particulate can be composed of any material including nuclear fuel). The terms "SNF Project" or "Hanford SNF Project" all refer specifically to the overall Hanford project that has responsibility for the recovery, transport and safer storage of both the SNF and sludge at the K Basins.

$\mathrm{N}$ Reactor fuel, the primary SNF in K Basins, has been stored there for extended periods of time. This fuel is degrading with continued storage, resulting in release of material to the basin water in $\mathrm{K}$ East Basin and to the closed storage canisters in $\mathrm{K}$ West Basin. Information on the condition of the fuel supports decisions for the removal, transport, conditioning, storage, and ultimate future disposal of the materials that are stored in the K Basins in both the open and closed canisters. The fuel must be placed in a safe interim storage condition for an extended period before ultimate disposal in a waste repository. The characterization activities for the Hanford SNF Project address the identified issues related to the condition of the fuel, which are continued degradation, fuel conditioning, and interim storage for an extended period of time.

The characterization activities for the estimated $50 \mathrm{~m}^{3}$ of sludge in the $\mathrm{K}$ Basins address the engineering needs for recovery, transport, and interim storage at the Hanford T Plant (prior to the sludge being moved with other Hanford transuranic waste to a facility such as the Waste Isolation Pilot Plant [WIPP]).

The characterization activities for both the SNF and the sludge are structured to support SNF Project design decisions for the path to interim storage, the Environmental Impact Statement (EIS) and corresponding Record of Decision (ROD), and the safety analysis reports. 
Revision 2 to this Characterization PMP reflected the corrective actions taken in response to the SNF Project Quality Assurance (QA) surveillance 1K-FY99-060. Inconsistencies between the PMP and the Q-List document (McCormack 2000) were corrected in conjunction with requested revisions to the Q-List. Organizational charts, interfaces, and functional responsibilities were updated to current status. Data recording requirements for scientific notebook entries were modified to reflect actual needs for SNF characterization investigations and sampling. Additionally, reference procedures were updated to those in current use.

The current revision to the PMP reflects the corrective actions required in response to the SNF Project Worker Assessment resolution SNF-KP-WA-WM-20001756. Inconsistencies between the Revision 2 and current organizational structure and responsibilities are corrected.

Particularly addressed are 1) the closeout and disbanding of the SNF Characterization Project group that had responsibility for the primary activities as assigned by the past versions of the PMP and 2) the corresponding transfer of responsibilities for characterization activities that will continue as subtasks under other SNF Project groups. Also addressed in this revision is a clearer definition of the activities and requirements related to the Sludge Handling Project, separating them more distinctly from the SNF requirements.

The characterization for the SNF is being performed to the Office of Civilian Radioactive Waste Management (OCRWM) QA requirements. Correspondingly, the PNNL QA plan is in full compliance with the related Quality Assurance Requirements and Description (QARD) as evidenced by the most recent audit of the PNNL Characterization Program (Lawrence 1997a). Because the sludge is ultimately to reside in a facility such as the WIPP, the characterization for the sludge is not being performed to the OCRWM QARD requirements. Activities for the Sludge Handling Project characterization tasks are being performed to the SNF Project Quality Assurance Program Plan (QAPP) (SNF-4948) that implements the FH Quality Assurance Program Description (QAPD) Document (HNF-MP-599).

\subsection{SCOPE, OBJECTIVES, AND PROGRAM RESPONSIBILITIES}

\subsection{SCOPE}

The scope of this PMP focuses on 1) the SNF [i.e., N Reactor and Single Pass Reactor fuel] stored in the Hanford K Basins and 2) the corresponding bulk sludge that has accumulated in the various locations of the $\mathrm{K}$ Basins.

Characterization activities have been, and will be, planned to obtain key information needed to support the SNF Project Path Forward decisions in the shortest period of time. Detailed characterization plans will be structured using the Data Quality Objective (DQO) process to support Path Forward project decisions (Lawrence et al. 1994). 


\subsection{OBJECTIVES}

The following objectives were established for the overall SNF Project Path Forward characterization activities:

1. Provide a guiding methodology for identification, collection, and reporting characterization data.

2. Support Multi-Canister Overpack (MCO) design decisions for transport and interim dry storage of the SNF within regulatory compliance.

3. Develop a database to support fuel processing for transition from current configurations to interim dry storage.

4. Support development of the safety envelope for fuel retrieval, MCO loading, cold vacuum drying, and transportation and storage in the Canister Storage Building.

5. Provide data to support interim storage and monitoring of the SNF.

6. Provide engineering design data to support the Sludge Handling Project to transport and store K Basins sludges at the Hanford T Plant (Pottmeyer 2000).

7. Support issuance of the SNF Project related EIS/ROD.

\subsection{Program Responsibilities}

The SNF Process Engineering group is responsible for the remaining characterization activities for the SNF in the K East and K West storage basins. The now disbanded SNF Characterization Project group was previously responsible for all aspects associated with program development, sample selection, sample retrieval, in-situ and laboratory measurements, data analysis, and reporting.

The SNF Project Sludge Handling Project group is responsible for the remaining characterization activities for the sludge in the K East Basin and K West Basin. Prior to Fiscal Year (FY) 2000, these activities were the responsibility of the SNF Characterization Project group.

\subsection{PROGRAM MANAGEMENT AND ORGANIZATION}

FH has responsibility for defining the envelope of requirements for characterization activities to support the SNF Project, for conducting in-situ characterization in the basins, for preparation and shipments of materials to the hot cells for examinations, for requests for information from the hot cell examinations, and for interpretation of the results for the SNF Project. FH is also responsible for supplying characterization information to support other project objectives. 
HNF-SD-SNF-PLN-010, Rev. 3

\subsection{WORK BREAKDOWN STRUCTURE}

The Work Breakdown Structure (WBS) for the characterization tasks will be fully integrated and consistent with the WBS for the SNF Project. Characterization activities will use the WBS developed by the SNF Project for the Multi-Year Program Plan (MYPP). The WBS can be obtained from the current MYPP.

\subsection{PROGRAM ELEMENT AREAS OF RESPONSIBILITY}

\subsection{Plan for Characterization OF K Basin SNF ANd Sludge}

The Plan for Characterization of K Basin SNF and sludge outlines the data needed to support the SNF and sludge Path Forward decisions (Trimble 2000). FH has the responsibility for preparation and maintenance of this Plan. This includes revisions as work progresses and data are obtained with corresponding increases in understanding of the material characteristics and conditions in the $\mathrm{K}$ Basins.

\subsection{K BASINS ChARACTERIZATION}

The characterization activities at $\mathrm{K}$ Basins include detailed review of historical records to establish parameters for the materials stored in the K Basins, in-situ examinations of the materials stored in the Basins, development of data on the fuel canisters and sludge in both $\mathrm{K}$ Basins, and evaluations of the data obtained during collection and analyses of the SNF and sludge samples at $\mathrm{K}$ Basins. FH has responsibility for characterization activities at $\mathrm{K}$ Basins, recognizing FH's primary responsibility for the $\mathrm{K}$ Basins operations and surveillance activities. Both PNNL and 222-S Laboratory staff will provide expert advice for K Basins characterization activities.

\subsection{TRANSPORTATION}

Materials will be transported between the $\mathrm{K}$ Basins and the various on-site laboratories and hot cells for examinations as part of characterization activities. FH will have the primary responsibility for all aspects of the movement of materials from one location to another (including 222-S Laboratory). Once material has been transported to a PNNL facility, it will become the responsibility of PNNL until it is returned to FH. The PNNL will be responsible for all material movements within and between their facilities and for disposal of test residuals. Historically, FH had the primary responsibility for preparation of the return shipments of SNF sample remains to $\mathrm{K}$ Basins.

\subsection{Quality Assurance}

For the SNF, the QA for the characterization activities and data management will be in compliance with the OCRWM QARD, RW-0333P (Sellers 1995), as specified in the following paragraphs. Sludge characterization is performed to the requirements of 10CFR830.120 as 
defined in the Project Hanford QAPD document (HNF-MP-599) and the corresponding SNF Project QAPP, SNF-4948. The characterization activities and data management will comply with the individual FH and PNNL QA requirements.

Characterization activities for the SNF are subject to independent oversight by the SNF Project QA and FH QA organizations. For a list of surveillance and audit or assessments planned for the Characterization activities, refer to the FH surveillance and FH Facility Evaluation Board assessment organization.

The characterization activities are structured to support design decisions for the interim storage of the fuel and sludge, the safety basis documents, and fuel conditioning. The test data collected is used either directly or indirectly to confirm the acceptable range of process conditions and/or to design nuclear safety structures, systems and components that will either prevent or mitigate releases to the off-site public or on-site workers that would exceed radiological risk guidelines called out in HNF-PRO-704. Therefore, these data collection activities are considered quality affecting and must be planned and performed under a QA program that is based on the requirements defined in the Project Hanford QAPD document (HNF-MP-599) and SNF Project QAPP, SNF-4948.

In addition, some of the SNF data collection activities will provide information that will either directly or indirectly impact processes or systems that will establish properties or behavioral characteristics for the final disposition of Hanford SNF in the geologic repository. Therefore, these activities also have to comply with OCRWM QARD RW-0333P. See Section 5.4.2 for a list of those OCRWM related activities.

\subsubsection{QA Organization Support for the SNF Project Characterization Activities}

The responsibilities for QA and the various tasks within the SNF Project characterization activities are defined in this section of the Characterization PMP. The overall organizational structure within the SNF Project for QA is summarized in Figure 1. The structure includes both the technical and line management responsibilities for characterization tasks and QA. The QA organization is structured to provide independent oversight and QA support to SNF Project tasks and satisfies the organizational responsibilities identified in the SNF Project QAPP.

The manager of the SNF Project Process Engineering group is responsible for all the SNF characterization tasks. The manager of the SNF Project Sludge Handling Project is responsible for all sludge characterization tasks. These tasks include responsibility for the following:

- Overall program scope and schedule

- Multi-year program funding

- Work assignments

- Interfaces with other SNF Project and Hanford organizations

- Overall responsibility for characterization data quality. 
HNF-SD-SNF-PLN-010, Rev. 3

Figure 1. SNF Project Organization Structure for Achieving Quality in Characterization Activities.

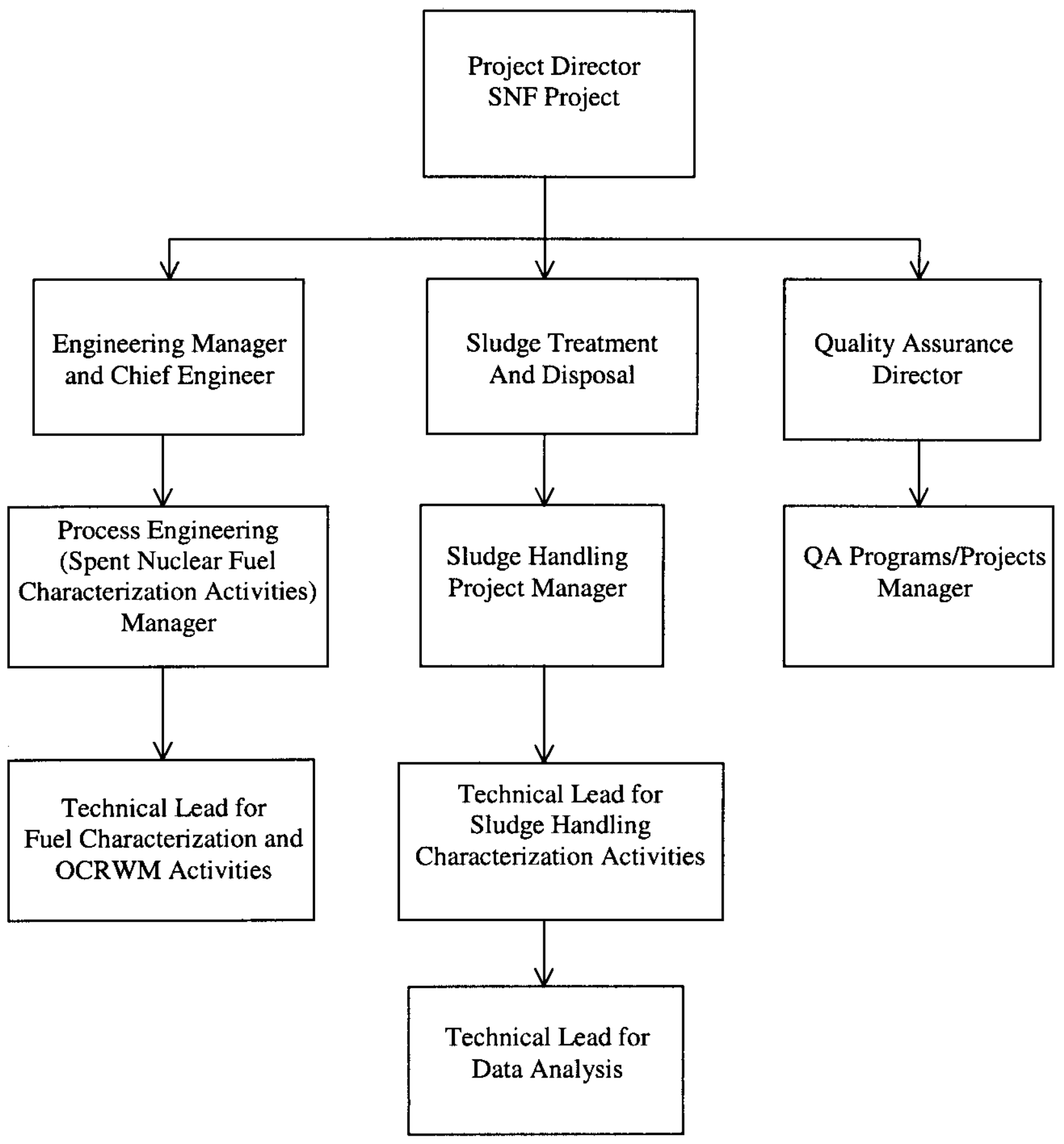


The SNF Project Characterization tasks are further divided into areas of responsibility (Figure 1) with a Lead Engineer identified as responsible for each area. In addition to the lead tasks, support roles are assigned that may include as applicable: equipment development, sample collection, laboratory interface, data collection, data analysis and reporting, and data storage: These assignments are made as required by the manager of the responsible SNF Project group.

\subsubsection{OCRWM QA Program}

Some of the characterization activities within the SNF Project were identified within the scope of the OCRWM QARD (McCormack 2000). Fundamentally, data generated concerning any fuel or related materials that are expected to be loaded into the MCOs falls within the scope of this QARD. The following SNF characterization activities were identified as falling within the OCRWM QARD (all have been completed, except for document review and final data qualification):

- In-situ fuel video examinations to cover fuel surface area and amount of particulate matter

- Metallographic examinations of fuel samples

- Small sample furnace fuel drying and ignition testing

- Whole fuel element drying studies

- Fuel subsurface sludge and surface coating examinations

- Thermo-Gravimetric Analysis (TGA) for fuel oxidation and fuel, sludge, and coating drying studies

\subsubsection{QA Controls}

The specific QA/Quality Control (QC) controls defined here that will be used to collect and analyze the data obtained from the SNF and sludge samples are based on practices recognized by the United States Environmental Protection Agency (EPA) for environmental sampling. It is recognized that a number of other management systems necessary to implement the $\mathrm{K}$ Basins SNFP QA program (e.g., Training/Qualification, Quality Improvement, Document/Records, Procurement, Management and Independent Assessments) are required to support these activities. However, because they are common to all SNF Project quality affecting functions they will not be specifically repeated here.

\subsubsection{DQO Development}

The DQO process is the scientific method used by the SNF Project for characterization activities to outline the data collection strategy. The DQO process is based on the EPA guidance document QA/G-4 (EPA 1993). The DQO process supports the sample collection design that will produce data of sufficient type, quantity, and quality to satisfy the data users needs and support technically defensible decision making. 
All SNF Project characterization sampling campaigns will be planned using the modified DQO process called out in SNF Project Characterization Data Quality Objectives Strategy (Lawrence et al. 1994). The results of the DQO process will be documented, issued, and controlled as an SNF Project Supporting Document in accordance with requirements in SNF Project Administrative Procedure (AP) EN-6-025.

In its simplest form, the DQO Process asks the program participants to address three key questions:

1. What data are required to answer the question(s) posed?

2. What new data are required?, and

3. How will the newly obtained data be used to answer the question(s) posed?

The SNF Project is fully committed to utilizing the DQO approach to define characterization needs (Lawrence et al. 1994). The DQO process will govern the development of the individual Sampling and Analysis Plans (SAPs), examination strategy documents, test plans and instructions prepared for each series or group of examinations or measurements. Section 5.4.4.1.1 discusses additional details of the DQO process as applied to characterization activities.

For the SNF, issued DQO documents will not be revised to update to the evolving programmatic requirements of the Project or to sampling and testing realities. Differences between planned and actual sampling and testing activities for the SNF will be documented and reconciled to the DQOs in the data validation process (Section 5.4.4.1.5). For the Sludge Handling Project activities, DQO documents will be revised to evolving project requirements as they occur.

\subsubsection{Sample Control (for Future New Samples)}

The requirements for control of any new samples of SNF taken in the future for SNF Project characterization activities are established in procedures HNF-PRO-1884 and AP EN-6-016. These procedures implement the necessary sample controls to assure compliance with the OCRWM QARD. These procedures were established for collection of samples of SNF taken at the $\mathrm{K}$ Basins and for sample control during laboratory testing and analysis.

Samples that do not meet the requirements specified in work controlling documents (e.g., Job Control System work packages, procedures, sample analysis plans, etc.) would be considered nonconforming and shall be documented and dispositioned using the nonconformance report process identified in AP QA-11-004.

Samples are considered nonconforming when the quality or integrity of the sample can no longer be assured. Examples of nonconformance are: Chain of Custody missing, sampling instructions were not followed, sample traceability is lost, and sample identification numbers were duplicated. 
At this point in time, no additional samples of SNF are planned; however, these procedures are provided as a contingent. Sample control for new samples of sludge will be established in the specific SAPs.

Samples of SNF and sludge taken prior to issuance of HNF-PRO-1884 had requirements for sample control documented in either work plans or SAPs. These typically included assignment of a unique sample identification number when the sample was taken, tracking of the sample with Chain-of-Custody or notebook methods from the field to the laboratory, and reporting of the unique identification numbers in the final data packages.

\subsubsection{Notebook Usage}

The SNF Project characterization activities used engineering notebooks to provide a chronological record of the fuel, sludge, and canister sampling activities. This information is used to supplement the information that is contained within the video tapes and other documents. The types of information that is recorded in the notebooks are:

- Observations of the operational condition of the sampling equipment and any significant problems that occur during the sampling activities (e.g., equipment failures, field repairs, or modifications, etc.)

- Qualitative values of field measurements taken that were not recorded elsewhere in test plans, work packages, or data sheets in the master work plan, etc.

- Movement of fuel canister's location during the sampling activities and its final location within the fuel pool once sampling was completed

- Sample traceability information to track sample identification numbers from the point of collection to the point of loading samples into the shipping cask

If a late entry must be made in a notebook, the information will be recorded in the next available space and shall indicate the actual time of occurrence and shall be identified as a late entry.

These notebooks are controlled in accordance with the requirements found in HNF-PRO-224 for controlled notebooks and logbooks. The instructions for record keeping practices that are to be followed are supplied with each book. For OCRWM related investigations, notebook use shall be in accordance with AP EN-6-015. A final review of the notebook will be performed by the notebook custodian for completeness and legibility prior to the book being retired and returned to Records Information Management or to the SNF Project File. This review will be documented in Section 2 of the notebook coversheet.

\subsubsection{QC Samples}

In order to monitor the overall performance of the analytical measurement system, QC samples will be taken in the field, the laboratory, or both. The Lead Engineer will determine what types of QC samples (e.g., equipment blanks, spikes, duplicates, etc.) are appropriate for each sampling campaign and identify them in the sampling documents or procedures. 


\subsubsection{Data Review and Validation}

Each analytical data package that is prepared by the laboratory will be internally reviewed by the laboratory to assure the following:

- SNF Project requirements, stated procedures, and protocols were correctly followed

- Required QC check samples, method control (calibration) standards, etc., have been performed and the results are within specified limits

- Analytical results are correct and accurate

- Analytical variability (e.g., precision, accuracy, etc.) are within specified tolerances

- Any data anomalies have been addressed

These requirements will be communicated to the performing laboratories by work plans, statements of work, SAPs, or similar documents.

The SNF Project will perform data validation (Section 5.4.4.1.5) on the characterization data collected to assure the project objectives (DQOs) have been satisfied and the data is suitable for its intended use. The SNF Project will document this review as specified in Section 5.4.4.1.5.

\subsubsection{Scientific Investigations}

Specific details of how the SNF and sludge characterization activities will be controlled and how final test reports will be prepared are provided in the following sections of this PMP. In addition, the SNF characterization activities fall within the QARD category of scientific investigations. All SNF work will be controlled to the SNF Project AP, Control of OCRWM Scientific Investigation Work, AP EN-6-015. As noted previously, sludge characterization activities do not fall within these QARD requirements.

\subsubsection{Control of Characterization Work}

The necessary planning activities, methods to acquire the data, analysis of the data, and data reviews to conduct the scientific investigations are described in the following sections.

\subsection{Planning Scientific Investigations}

The responsible Lead Engineer will plan each SNF and sludge sampling campaign using the DQO process described in the Characterization Data Quality Objectives Strategy document (Lawrence et al. 1994). Upon completion of the first six steps of the process, the Lead Engineer should be able to define the following information:

- Who are the data users (stakeholders) and what their data needs are

- Who is (are) the individual(s) responsible for making the final decisions (key decision maker) 
- List of the objectives or problems (decisions) that the sampling campaign must address

- Identify the problem resolution strategy for each of the listed objectives

- Define the technical information that must be collected or known in order for the objectives to be achieved

- Identify the logic (decision rule) that will be used to resolve the objectives with the information collected

- Identify the accuracy, precision, and representativeness (decision error) required of the results in order to make correct decisions

The Lead Engineer will take the information obtained from the DQO process and following the formatting guidelines in WHC-EP-0795 prepare a DQO document that will be issued as a Project Document. Because of the wide spectrum of data needs, the SNF Project characterization DQO process is designed to be flexible and allows the degree of detail and depth to which the process is followed to vary with each sampling campaign. Depending upon the data needs and how well defined and mature the information available to support a decision are, the Lead Engineer may not be able to complete each step of the process. In those cases he or she will simply identify which steps of the DQO process are applicable or not.

The Lead Engineer will complete the DQO process by formulating a sample collection scheme or strategy that will best satisfy the SNF Project decisions and data needs. A SAP will be used for the sludge samples. An examination strategy or plan will be prepared for the fuel elements selected and the associate samples removed from these elements. These will be issued either as part of the DQO document or as a separate Project Document. As applicable, these documents will contain the following types of information:

- The number of samples to be taken

- The locations of where the samples will be taken (e.g., fuel element or canister number)

- The type, number, and frequency of QC samples to be taken (e.g., duplicates, blanks, etc.)

- The sampling and analytical test procedures that will be used

- Any special instructions for handling, subdividing, or compositing the samples

- Any required field measurements that needs to be taken

- Any special instructions regarding sample preparation and analysis

\subsection{Acquiring the Data}

The Lead Engineer will be responsible for preparing either a work package in accordance with AP MS-7-002 or Technical Procedure in accordance with AP MS-9-002 to control sample collection activities within the Basin. Depending upon the complexity of the task, additional work control documents (e.g., test instructions, procedures, etc.) may be required to provide the test operators and test engineers with sufficient instructions for performing the sampling. 
Sampling personnel are responsible for physically identifying sample containers with the appropriate sample identification numbers as called out in the work package. In addition, sampling personnel will initiate a Chain of Custody and a Sample Analysis Request form for each of the samples collected.

Any field measurements taken at the time of sampling will be traceable to the location or item taken. Data taken will be recorded on a Master Work Plan, the Technical Procedure, on forms that are included as part of approved procedures, or in engineering notebooks.

\subsection{Conducting the Analysis}

Prior to collecting the sample, the Lead Engineer is responsible for establishing an analytical services contract (or equivalent) with either an on-site or off-site laboratory for any physical or chemical testing required. Procurement documents or work agreement documents (e.g., Letter of Instruction, Statements of Work, etc.) will be prepared in accordance with the requirements found in Section 7.0 of the SNF Project QAPP, SNF-4948. These procurement documents, as applicable, shall address the following:

- The scope of the analytical testing required

- The analytes or physical characteristics of interest

- The anticipated number of samples, along with a sample collection schedule

- Matrices to be sampled (e.g., sludge or fuel samples)

- The required analytical testing methods, including any necessary detection limits

- Any precision, accuracy, and completeness requirements to satisfy the DQOs

- QA requirements, including required laboratory control samples

- Data reporting requirements and required documentation to be submitted for FH review

- Data verification and data review requirements

Testing that is performed by FH will be conducted in accordance with approved test plans, instructions, or procedures per the requirements in HNF-PRO-1819. Test results will be documented in a test report prepared in accordance with AP EN-6-025 or as directed in the work instructions.

The laboratory will prepare an analytical data package(s) to document the test results. These packages shall meet the requirements specified in the procurement documents or work agreement documents covering the laboratory's work scope and should contain, as applicable, the following information:

- Analytical results traceable to the original sample identification numbers. If unique laboratory identification numbers are used a cross reference to the project's sample information must also be included

- The results of all required analysis including duplicate results

- The results of all QC data (e.g., spike recovery results, laboratory control standard results, trip, hot cell or equipment blank results, etc.) 
- Deviations from established procedures or SNF Project instructions, along with the reason for the deviations

- Other data anomalies, outliners or deficiencies and their impact on the data

- Narrative summarizing the analysis results and the quality of the results

- Identification of the author or individual responsible for the content of the report

Laboratory test data reports may also include a summary of all the test data in cases where significant quantities of data are generated as computer files. The database will be stored in accordance with the laboratory's records/data management practices as described in their QA plan in order to reproduce the summary information provided in the test report.

\subsection{Data Traceability}

Characterization data will be traceable back to the original sample identification number. Through the sample identification number, the documentation associated with the sample collection, analysis, and evaluation can be located.

Characterization related documents (e.g., summary reports, final test reports, validation reports, etc.) reporting the SNF data acquired and/or developed for OCRWM use shall identify the OCRWM qualification status of the data in accordance with AP EN-6-015. Data qualification status shall be indicated as or similar to the following:

- "Qualified from origin" Data that was acquired and/or developed under a QA program based on the DOE-RW-0333P QAPD

- "Existing" Data that has not been collected under a QA program based on the DOE/RW-0333P QAPD and if used for OCRWM related work will have to be qualified in accordance with the requirements in AP EN-6-015 "Control of OCRWM Scientific Investigation Work"

- "Qualified" Existing data that has been OCRWM qualified in accordance with AP EN-6-015

Current qualification status will be maintained in the SNF Project Technical Databook (HNF-SD-SNF-015, Vol. 1).

\subsection{Data Validation}

The Lead Engineer is responsible to review the test results for technical adequacy and to assure the data obtained meets the intended end use as specified in the DQOs. The data validation results will be documented (e.g., test reports, etc.) to satisfy the documentation requirements of Section 5.4.3.5.

Data that is found unacceptable for its intended end use will be identified as such in the test report or in a subsequent characterization summary report. In addition, the Lead Engineer will have to determine if further sampling and analysis needs to be performed to either confirm or negate the data anomalies found or whether a corrective action plan is required to reassess the 
validity of the sampling strategy used. If the data is determined to be unnecessary, that information, along with a justification for why it is not required, will be included in the Lead Engineer's review.

\subsubsection{Final Test Reports}

Final test reports will be prepared for the fuel and sludge examinations. Reports that document tests that fall within the scope of the OCRWM QARD (McCormack 2000) will be reviewed in accordance with AP EN-6-009, OCRWM Reviews. Reviews directed by PNNL for reports they prepare will be conducted in accordance with their QA plans and procedures. Those PNNL reports that document OCRWM activities or data will be reviewed in accordance with PNNL OCRWM QA plans. The following sections of this PMP identify the FH and PNNL reports that will require OCRWM reviews.

\subsection{FH Reports for OCRWM Review}

Reports to be prepared by FH that are within the scope of the OCRWM QARD are listed in Table 1. These reports will be reviewed in accordance with the AP EN-6-009.

\subsection{PNNL Reports for OCRWM Review}

Reports prepared by the PNNL for the SNF Project characterization activities in the following areas are within the scope of the QARD and will be provided an OCRWM review in accordance with the PNNL QA plans. All reports covering these topics are listed in Table 2.

- Small sample furnace drying and ignition testing

- Whole element drying studies

- Metallographic examinations of fuel samples

- TGA for oxidation 
Table 1. OCRWM QARD Reports by FH

\begin{tabular}{|l|l||}
\hline \multicolumn{1}{|c|}{ Report Number } & \multicolumn{1}{c|}{ Report Topic } \\
\hline HNF-2586 & Summary Assessment of Fuel Damage Distributions \\
\hline HNF-2314 & Statistical Analysis of Fuel Visual Examination Data \\
\hline HNF-2853 & Reaction Rate of Uranium in Water and Water Vapor \\
\hline HNF-3283 & Aluminum Hydroxide Coating Thickness Measurements \\
\hline HNF-3377 & Drying Damaged K West Fuel Elements (Summary) \\
\hline HNF-3589 & Analysis of K West Fuel Internal Sludge and Coatings \\
\hline HNF-4206 & Oxidation of K Basin Fuel \\
\hline SD-SNF-CN-019 & Reaction Rate Constant for Dry Air Oxidation of Fuel \\
\hline SD-SNF-TI-012 & K East Basin Underwater Visual Fuel Survey \\
\hline SD-SNF-TI-018 & K East Fuel Cleanliness Evaluation \\
\hline SD-SNF-TI-045 & Visual Examinations of K East Fuel Elements \\
\hline SD-SNF-TI-046 & Visual Examinations of K West Fuel Elements \\
\hline SD-SNF-TI-060 & K Basin Fuel Subsurface and Coating Examinations \\
\hline SD-SNF-TRP-015 & Sludge Adherence Summary Report \\
\hline
\end{tabular}

Table 2. OCRWM QARD Reports by PNNL

\begin{tabular}{||l|l||}
\hline \multicolumn{1}{|c|}{$\begin{array}{c}\text { Report } \\
\text { Number }\end{array}$} & \multicolumn{1}{c|}{ Report Topic } \\
\hline PNNL-11438 & $\begin{array}{l}\text { Metallographic Examination of Damaged N Reactor Spent Nuclear Fuel } \\
\text { Element SFEC5,4378 }\end{array}$ \\
\hline PNNL-11786 & Dry Air Oxidation Kinetics of K Basin Spent Nuclear Fuel \\
\hline PNNL-11806 & Examinations of Surface Coatings Removed from K East Basin Fuel Elements \\
\hline PNNL-11814 & Spent Fuel Drying System Test Results (First Dry Run) \\
\hline PNNL-11816 & Analysis of Ignition Testing on K West Basin Fuel \\
\hline PNNL-11817 & Drying Results of K Basin Fuel Element 1990 (Run 1) \\
\hline PNNL-11818 & Drying Results of K Basin Fuel Element 3128W (Run 2) \\
\hline PNNL-11820 & Drying Results of K Basin Fuel Element 0309M (Run 3) \\
\hline PNNL-11821 & Drying Results of K Basin Fuel Element 5744U (Run 4) \\
\hline PNNL-11838 & Spent Fuel Drying System Test Results (Second Dry Run) \\
\hline PNNL-11841 & Drying Results of K Basin Fuel Element 6603M (Run 5) \\
\hline PNNL-11844 & Oxidation Rate of K Basin Spent Nuclear Fuel in Moist Air \\
\hline PNNL-11896 & Drying Results of K Basin Fuel Element 1164M (Run 6) \\
\hline PNNL-11897 & Drying Results of K Basin Fuel Element 2660M (Run 7) \\
\hline PNNL-11932 & Drying K West Internal Sludge and Surface Coatings \\
\hline PNNL-11969 & Drying Results K Basin Fuel Element 6513U (Run 8) \\
\hline PNNL-12167 & Oxidation of K Basin SNF in Moist Helium \\
\hline
\end{tabular}




\subsection{WASTE MANAGEMENT}

A Waste Management Plan was prepared that describes, in detail, the pathway for disposal of all wastes generated from SNF Project characterization activities (Chastain 1994). FH will have responsibility for all wastes designated as SNF, excess sludge sample materials (Williams 1996), and all wastes generated at $\mathrm{K}$ Basins. The PNNL and 222-S Laboratories will have responsibility for disposal of all related test residuals generated in their facilities.

\subsection{DATA INTERPRETATION}

Data interpretation is a central part of the plan for characterizing the SNF and $\mathrm{K}$ Basins sludge. For the SNF this will be a shared FH and PNNL activity. These data interpretations may be performed by an individual or a team. A team will capitalize on expertise within each organization for interpretation of individual types of data as well as groups of data addressing specific questions such as extent of fuel oxidation and hydriding, etc. Interpretations and conclusions reached will be conveyed to the SNF Project through the FH Management Points of Contact (Section 6.1). FH is responsible for the resolution, to the satisfaction of Department of Energy, Richland Operations Office (RL), of all differences of opinion. The evaluations will be documented as needed in an Engineering Support Document and issued in accordance with AP EN-6-025.

For sludge, the SNF Project Sludge Handling Project group will be responsible for coordinating all data interpretation activities on a case-by-case basis, consistent with DQOs and SAPs.

\subsection{National SNF Program}

The Hanford SNF Project recognizes that there is a National SNF Program with a stake in the issues related to the fuel materials within the Hanford Site as they pertain to final disposition in a waste repository after interim storage at Hanford. The SNF Project will participate in the National Program, as authorized by the National SNF Program Management Points of Contact (Section 6.1). The PNNL may continue to participate in National SNF Program Meetings representing its interest as a National Laboratory, but will not represent the SNF Project unless requested.

\subsection{PROGRAM INTERFACES AND COMMUNICATIONS}

\subsection{Management Points of Contact}

The FH Management Points of Contact for SNF Project characterization activities are 1) for the SNF the manager of the Process Engineering, and 2) for sludge handling the manager of the Sludge Handling Project.

The Management Point of Contact for the National SNF Program is the Project Manager of SiteWide SNF Disposition. 
The Project Manager Points of Contact for the sludge laboratory activities at PNNL is K. L. Silvers, and at the 222-S Laboratory is D. A. Dodd.

The Management Points of Contact are the formal interfaces between the organizations. They are responsible for the program interfaces and communications for their respective organizations.

As responsibilities change for any of these individuals, as appropriate, notification should be made to the other Management Points of Contact.

\subsection{Lead Engineers, Principal Investigators, and TASK Team Leaders}

Lead Engineers, principal investigators, and task team leaders will be appointed from the SNF Project and its supporting organizations to fully utilize expertise within each for specific activities. These individuals will be identified by the Management Points of Contact within the respective organizations. Appointments to a specific task or activity will be communicated to all interested parties within the organizations. These individuals will act as the single points of contact for that specific task or activity within the characterization activities.

\subsection{INTERFACE WITH SNF PROJECTS}

The FH Management Points of Contact for characterization activities will be the interfaces and communications links to the rest of the SNF Project.

\subsection{Interfaces With Other Hanford Projects}

Single point of contact interfaces will be defined by the FH Management Points of Contact for other Hanford Projects and RL as appropriate.

\subsection{MEETINGS}

\subsection{Periodic Activity Meetings}

Periodic activity meetings will be held with appropriate participants, as necessary to maintain activities on-schedule. Meetings will be called by the respective Lead Engineer, principle investigator, task team leader, or Management Point of Contact.

\subsection{REPORTS AND DOCUMENTATION}

\subsection{Topical Reports and OPEn Literature PUblications}

Timely reports at the completion of an activity are required of the organization with the primary responsibility or lead for that activity. Preparation of topical reports are encouraged. However, letter reports may be acceptable on a limited basis for small activities or for timely distribution of 
results. Open literature publications within the appropriate forum are encouraged. Open literature publications must have SNF Project approval prior to release from other organizations. Any issued reports should include the appropriate SNF Project File as part of the distribution.

\subsection{Plans, Requirements, AND Routine Correspondence}

Examination plans, data requirements, and routine correspondence generated within the characterization activities will be made available to all interested parties. In order to expedite the document approval process, early drafts and parallel reviews will occur without regard to organization. The intent is to provide free and timely exchanges of information to all interested parties. Any significant documents should include the appropriate SNF Project file as part of the distribution.

\subsection{SCHEDULES AND COMMITMENTS}

\subsection{Overall Project Schedules}

The overall project and activity schedules are structured around the SNF Project Path Forward strategy for removal of fuel and sludge from the K Basins. A key element in this is the integrated schedule for $\mathrm{K}$ Basin activities and projects. Also included are completion of the EIS/ROD, completion of the safety analysis reports, completion of drying, interim storage of the fuel, and removal of the sludge from $\mathrm{K}$ Basins with interim storage in T Plant (Pottmeyer 2000).

\subsection{Characterization Activities Schedule and Milestones}

Activity and milestone schedules have been established in the MYPP, in the Plan for Characterization of K Basin SNF and Sludge, and in specific planning for the related SNF Project subtasks such as sludge handling. These schedules are fully responsive to the overall SNF Project schedules. Task schedules will be reconciled by the Management Points of Contact to satisfy the overall project milestones and deliverables, and will be made available to all the Management Points of Contact and to the working level organizations to fully integrate activities to meet established milestones.

\subsection{FUNDING}

The identification and allocation of funds for characterization activities will be provided through the SNF Project MYPP Documentation. 


\subsection{PROGRAM MANAGEMENT PLAN REVISIONS}

The intent of this PMP is to set the framework for the plan to characterize the SNF and sludge at the Hanford $\mathrm{K}$ Basins (Trimble 2000). If there is a significant revision in the related tasks of the SNF Project work scope and the defined responsibilities of $\mathrm{FH}$ and other designated organizations, a revision to this PMP will be prepared. Changes to the PMP and associated plans will be managed through formal change control and reference baseline management documents.

\subsection{REFERENCES}

Chastain, S. A., and R. L. Spinks, 1994, Waste Management Plan for Hanford Spent Nuclear Fuel Characterization Activities, WHC-SD-SNF-PLN-001, Rev. 0, Westinghouse Hanford Company, Richland, Washington.

EPA, 1993, "Guidance for Planning for Data Collection in Support of Environmental Decision Making Using the Data Quality Objectives Process," EPA QA/G-4 Interim Final, U.S. Environmental Protection Agency, Washington, D.C.

Lawrence, L. A., 1998, Strategy for Phase II Whole Element Furnace Testing K West Fuel, HNF-2315, Rev. 0, Duke Engineering \& Services Hanford, Inc., Richland, Washington.

Lawrence, L. A., 1997a, Letter to S. C. Marschman, PNNL, "Transmittal of Duke Engineering \& Services Hanford, Inc. Audit Report," DESH-9759901, Duke Engineering \& Services Hanford, Inc., Richland, Washington.

Lawrence, L. A., 1997b, Strategy for Examination of the Fifteen $K$ West Basin Fuel Elements, HNF-SD-SNF-SP-018, Rev. 0, Duke Engineering \& Services Hanford, Inc., Richland, Washington.

Lawrence, L. A., 1996, Strategy for Examination of the Initial Nine K East Basin Fuel Elements, WHC-SD-SNF-SP-014, Rev. 0, Westinghouse Hanford Company, Richland, Washington.

Lawrence, L. A., K. S. Redus, and T. A. Thornton, 1994, Spent Nuclear Fuels Project Characterization Data Quality Objectives Strategy, WHC-EP-0795, Westinghouse Hanford Company, Richland, Washington.

McCormack, R. L., 2000, Application of the Office of Civilian Radioactive Waste Management Quality Assurance Requirements to the Hanford Spent Nuclear Fuel Project, HNF-SD-SNF-RPT-007, Rev. 4, Fluor Hanford, Inc., Richland, Washington.

Pottmeyer, J. A, et al., 2000, Project Execution Plan for the Sludge Handling System Project A-13(b), HNF-7287, Rev. 0, Fluor Hanford, Inc., Richland, Washington. 
Sellers E. D. (RL), 1995, Letter to President WHC, "Office of Civilian Radioactive Waste Management (OCRWM)," Quality Assurance Requirements and Description (QARD), RW-033P, 95-SFD-098, Westinghouse Hanford Company, Richland, Washington.

Trimble, D. J., 2000, Plan for Characterization of $K$ Basin Spent Nuclear Fuel and Sludge, WHC-SD-SNF-PLN-007, Rev. 2, Fluor Hanford, Richland, Washington.

Williams, N. H., 1996, "Sludge Disposal Plan of Execution," letter 96566039 to E. D. Sellers (RL), dated 1996, Duke Engineering \& Services Hanford, Richland, Washington. 